\title{
Review
}

\section{Recent advances on controllable and selective catalytic oxidation of cyclohexene}

\author{
Hongen Cao a, Boran Zhu a, Yufan Yang a, Lin Xu a,b, Lei Yu a,*, Qing Xu a,\# \\ a School of Chemistry and Chemical Engineering and the Institute of Pesticide of School of Horticulture and Plant Protection, Yangzhou University, \\ Yangzhou 225009, Jiangsu, China \\ bJiangsu Yangnong Chemical Group Co. Ltd., Yangzhou 225009, Jiangsu, China
}

\section{A R T I C L E I N F O}

\section{Article history:}

Received 8 January 2018

Accepted 15 February 2018

Published 5 May 2018

\section{Keywords:}

Cyclohexene

Selective oxidation

Green chemistry

7-Oxabicyclo[4.1.0]heptane

Cyclohexane-1,2-diol

Adipic acid

Cyclohex-2-en-1-ol

Cyclohex-2-en-1-one

\begin{abstract}
A B S T R A C T
Because of multiple potential reaction sites and variable oxidation depths, oxidation of cyclohexene can lead to a mixture of products with different oxidation states and functional groups, such as 7-oxabicyclo[4.1.0]heptane, trans/cis-cyclohexane-1,2-diol, cyclohex-2-en-1-ol, cyclohex-2-en-1-one, and even adipic acid. These products are broadly and abundantly used intermediates in the chemical industry; therefore, controllable oxidation reactions for cyclohexene that can selectively afford the targeted products are synthetically valuable for applications in both the academy and industry, thus becoming the aim of synthetic and catalytic chemists in the field. Many reports on selective oxidation of cyclohexene have recently appeared in the literature because of its significance. This short review summarizes the recent advances on this subject, and the contents are mainly classified based on the chosen oxidants. We hope that this review can provide a useful guide for controllable and selective catalytic oxidation of cyclohexene for interested readers from both the academy and industry.
\end{abstract}

(C) 2018, Dalian Institute of Chemical Physics, Chinese Academy of Sciences. Published by Elsevier B.V. All rights reserved.

\section{Introduction}

Cyclohexene (1) is a cheap, abundant, and easily accessible raw material in industry that is mostly produced through selective hydrogenation of benzene [1-3]. Though simple in its chemical structure, there are two potential oxidation sites in cyclohexene, and the usual oxidation reactions generally lead to a mixture of products with different oxidation states and functional groups (Scheme 1): oxidation of the $\mathrm{C}=\mathrm{C}$ bond (site $a$ ) can lead to 7-oxabicyclo[4.1.0]heptane (2), trans/cis-cyclohexane1,2-diol (3), or adipic acid (4); oxidation at the allylic C-H position (site b) may produce cyclohex-2-en-1-ol (5) or cyclo- hex-2-en-1-one (6). Since these products (2-6) are useful industrial intermediates that have been widely employed in organic synthesis, medicinal chemistry, pesticide chemistry, materials science, etc. [4-7], selective oxidation of cyclohexene to produce one of these chemicals is synthetically valuable for applications in both the academy and industry. Hence, this subject has attracted the interest of synthetic and industrial chemists. In recent years, many reports have appeared for selective catalytic oxidation of cyclohexene. During our own research on green catalysis and synthesis [8-17], we have also been engaged in this area [15-17]. We found that reviews on this subject were rare [18]. Therefore, this short review sum-

\footnotetext{
* Corresponding author. Tel: +86-13665295901; Fax: +86-514-87975244; E-mail: yulei@yzu.edu.cn

\# Corresponding author. Tel: +86-13857745327; Fax: +86-514-87975244; E-mail: xuqing@yzu.edu.cn

This work was supported by the National Natural Science Foundation of China $(21202141,21672163)$ and Priority Academic Program Development (PAPD) of Jiangsu Higher Education Institutions.

DOI: 10.1016/S1872-2067(18)63050-5 | http://www.sciencedirect.com/science/journal/18722067 | Chin. J. Catal., Vol. 39, No. 5, May 2018
} 


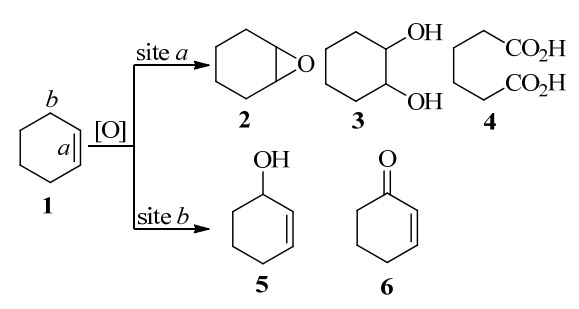

Scheme 1. Reaction paths of cyclohexene oxidation.

marizes the recent advances in this area; the contents are mainly classified based on the chosen oxidants. We hope that this review can provide a useful guide for controllable and selective catalytic oxidation of cyclohexene for interested readers from both the academy and industry.

\section{Oxidation using a chemical oxidant}

As an olefin, cyclohexene $\mathbf{1}$ can be oxidized by stoichiometric $\mathrm{KMnO}_{4}$ under strong acid conditions to produce adipic acid 4 (Eq. (1)). This reaction is well documented in textbooks [19]. Although the reaction provides adipic acid 4, a useful industrial intermediate, in a very high yield, the reaction could not be applied to large-scale production because a large amount of manganese solid waste is generated.

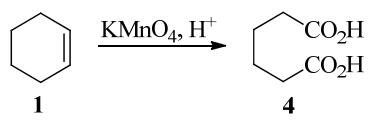

Analogously, other reactions using chemical oxidants that lead to solid waste are less applicable to industrial production, but they have been reported in recent years as an example of alkene oxidation to evaluate the catalyst activity. For example, in 2017, Kim et al. [20,21] designed and prepared nickel complexes $\mathbf{7}$ and $\mathbf{8}$ (Fig. 1), which were efficient catalysts in alkene oxidation reactions. Catalyzed by $\mathrm{Ni}(\mathrm{dpaq}) \mathrm{Cl}$ (7), cyclohexene could be oxidized by $m$-chloroperoxybenzoic acid ( $m$-CPBA) to give epoxide 2 in $40 \%$ yield, while generating allylic oxidation byproducts 5 and 6 (Eq. (2)) [20]. Dinuclear Ni complex 8 was an even better catalyst, affording $\mathbf{2}$ in an enhanced yield of $65 \%$, and the generation of allylic oxidation byproducts 5 and $\mathbf{6}$ was further restrained (Eq. (2)) [21]. Similarly, the oxidation reactions of cyclohexene by $m$-CPBA were also employed to evaluate the catalytic activities of cobalt complexes by the same group [22,23].
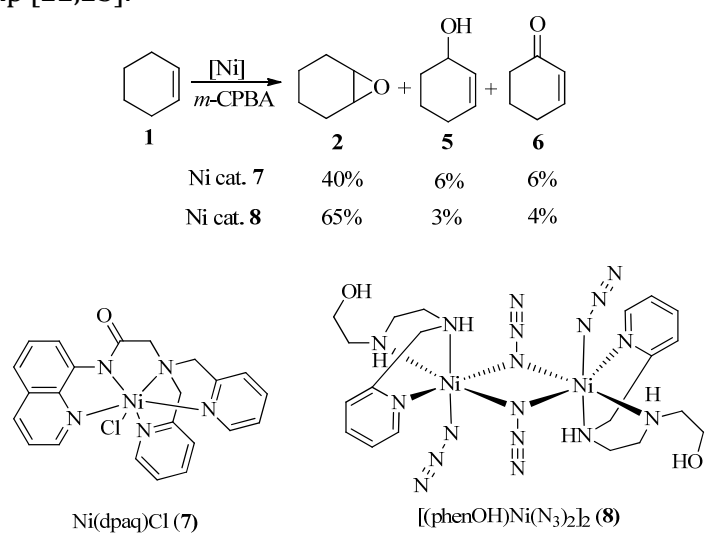

Fig. 1. Chemical structures of the Ni complexes.
Hypervalent iodine compounds are also popular oxidants in organic reactions, including the epoxidation of cyclohexene. For example, in the presence of the iron tris(pentafluorophenyl)corrole complex [Fe"II(TPFC)], cyclohexene was oxidized by a slight excess of (diacetoxyiodo)benzene to produce epoxide $\mathbf{2}$ at an excellent yield (Eq. (3)). The reaction was impressively fast and it finished within 10 min under mild conditions [24]. Besides Fe [24,25], the oxidation reaction of cyclohexene by hypervalent iodine reagents was catalyzed by complexes of other transition metals, such as $\mathrm{Cu}$ and $\mathrm{Mn}$, and was reported as an example for substrate extension of the alkene oxidation reactions $[26,27]$.

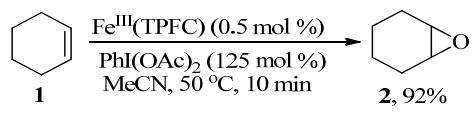

\section{Oxidation using $t$-BuOOH}

$t$ - $\mathrm{BuOOH}$ is cleaner than other chemical oxidants (e.g., metal salts/oxides, MCBPA, or $\left.\mathrm{PhI}(\mathrm{OAc})_{2}\right)$ because the reduction by-product of this reagent is $t-\mathrm{BuOH}$, a small organic molecule without hazardous elements (e.g., $\mathrm{Cl}, \mathrm{Br}$, and $\mathrm{S}$ ) that can be easily removed by distillation and recycled or eliminated by incineration. Therefore, oxidation methods with $t$ - $\mathrm{BuOOH}$ as the oxidant are more acceptable for industrial production, regardless of cost. There have been many examples of cyclohexene oxidation using $t$-BuOOH as the oxidant.

In 2002, Corey et al. [28] reported Pd-catalyzed selective allylic oxidation reactions of cyclohexene with $t$ - $\mathrm{BuOOH}$, in which the reaction selectivities were controlled by the catalyst system: The Pd/C-catalyzed reaction afforded cyclohex-2-en-1-one 6 in a 79\% yield (Eq. (4)); interestingly, with the $\mathrm{Pd}(\mathrm{OAc})_{2}$ catalyst and BINAP ligand, allylic tert-butylperoxy ether 9 was obtained as the major product (Eq. (5)). The reactions have been successfully applied on a series of cyclic, chained, aromatic, or aliphatic alkene substrates and should occur via a $t$-Bu00-free radical-mediated mechanism under basic conditions [28]. Copper-catalyzed allylic oxidation of cyclohexene by $t$-BuOOH was also investigated, and $\mathrm{CuCl}_{2} / L$-proline was shown to be a good catalyst system in water, affording the full conversion of cyclohexene and a very high cyclohex-2-en-1-one 6 selectivity at $92 \%$ [29].

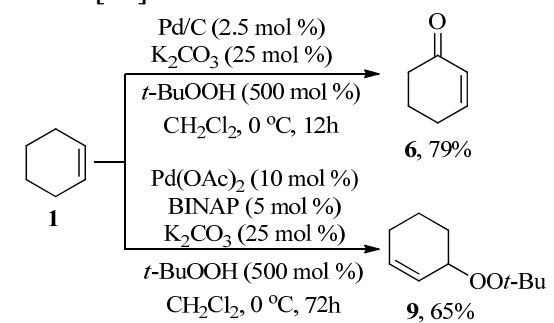

Besides the conventionally employed metal catalyst/ligand systems, a series of novel metal complex catalysts or ligands has been developed to achieve controllable and selective catalytic oxidation reactions with $t$-BuOOH (Fig. 2). Table 1 summarizes several typical examples. In 2004, Doyle et al. [30] reported a dirhodium caprolactamate catalyst $\mathbf{1 0}$ (Fig. 2), which was efficient for allylic oxidation of cyclic alkenes and could 


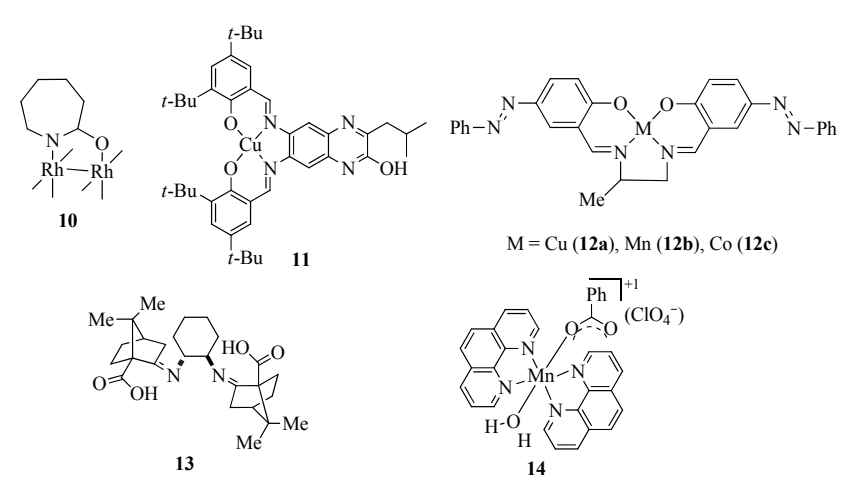

Fig. 2. Metal complexes or ligands employed in cyclohexene oxidation by $t$-BuOOH.

\section{Table 1}

Metal complex-catalyzed oxidation of cyclohexene by $t-\mathrm{BuOOH}$ to cyclohex-2-en-1-one 6.

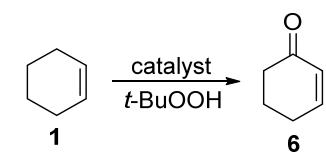

\begin{tabular}{|c|c|c|c|c|}
\hline Entry & Catalyst a & Condition & $6 \mathrm{6} / \%$ & Ref. \\
\hline 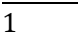 & $10(0.1 \%)$ & 5 eq. $t-\mathrm{BuOOH}, \mathrm{CH}_{2} \mathrm{Cl}_{2}, 40^{\circ} \mathrm{C}, 1 \mathrm{~h}$ & $>60$ & {$[30]$} \\
\hline 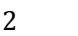 & $11(0$ & 3 eq. $t$-BuOOH, $\mathrm{MeCN}, 70^{\circ} \mathrm{C}, 1 \mathrm{~h}$ & (74) & [31] \\
\hline & & & $(87)$ & {$[32$} \\
\hline+ & 1 & $\operatorname{lux}$ & $(57)$ & {$[32]$} \\
\hline 5 & 12c $(1.8 \%)$ & 2.5 eq. $t-\mathrm{BuOOH}, \mathrm{MeCN}$, reflux & $(100)$ & [32] \\
\hline 6 & $\begin{array}{c}\mathrm{Mn}(\mathrm{OAc})_{2} 4 \mathrm{H}_{2} \mathrm{O}+ \\
13(5 \%)\end{array}$ & 2 eg $t-\mathrm{BuOOH}$ & $>85$ & [33] \\
\hline & $14(0.5 \%)$ & 8 eq. $t$-BuOOH, $\mathrm{MeCN}, 70^{\circ} \mathrm{C}, 1.5 \mathrm{~h}$ & $(76)$ & [34] \\
\hline
\end{tabular}

${ }^{a}$ Metal complex or metal salt with a ligand employed as the reaction catalyst (Fig. 2); Molar ratio of the catalyst or ligand versus cyclohexene inside the parentheses. ${ }^{b}$ Without parentheses: isolated yield of 6; Inside parentheses: GC yield of 6 .

produce cyclohex-2-en-1-one 6 in more than $60 \%$ yield from cyclohexene (Table 1, entry 1). Later, Gorden et al. [31] developed copper complex 11 (Fig. 2) to catalyze the allylic oxidations with $t$-BuOOH and produce cyclohex-2-en-1-one 6 in 74\% GC yield form cyclohexene. The reactions employed a reduced amount of oxidant and were conducted in a non-halogen solvent (Table 1, entry 2). Metal-Schiff base complexes 12a-c could also catalyze the oxidation of cyclohexene by $t-\mathrm{BuOOH}$ (Fig. 2) [32]. Catalyzed by 12a, the reaction afforded 6 in $87 \%$ yield, while cyclohex-2-en-1-ol $\mathbf{5}$ was also generated in $6 \%$ yield (Table 1, entry 3 ). The yield of $\mathbf{6}$ decreased when $\mathbf{1 2 b}$ was used as the catalyst because of the enhanced generation of $\mathbf{5}$ in $16 \%$ yield and other by-products in $27 \%$ yield (Table 1, entry 4). Co-Schiff base complex 12c was a favorable catalyst, quantificationally affording 6 (Table 1, entry 5). Using a cyclohexane-1,2-diamine-derived nitrogen bidentate ligand 13 , the catalytic activity of Mn was enhanced and could quickly produce 6 in more than $85 \%$ yield in dichloromethane (DCM, Table 1, entry 6) [33]. The Mn complex 14 was easily synthesized from $\mathrm{Mn}\left(\mathrm{ClO}_{4}\right)_{2}$ with 1,10-phenanthroline and benzoic acid, and it could catalyze the oxidation of cyclohexene by $t$-BuOOH to produce cyclohex-2-en-1-one 6 in 76\% GC yield (Table 1, entry 7) [34].
The reactions were also catalyzed by the supported/heterogeneous catalysts (Table 2). The product selectivity was determined by the catalyst reaction site. Different from transition-metal-catalyzed reactions, the reactions over the acid site generate $\mathrm{C}=\mathrm{C}$ oxidation products, such as epoxide $\mathbf{2}$ and diol 3. Catalyzed by the new mesoporous titanosilicate MCM-36 material [A-40Si/Ti-MCM-36(E)], the reaction produced epoxide 2 in 58\% yield (Table 2, entry 1) [35]. Ti in the catalyst was the active acid site of the reaction. The $\mathrm{Al}$ content in the catalyst largely affected the reaction. The strong $\mathrm{Al}$ acid sites could decompose the $t$ - $\mathrm{BuOOH}$ oxidant and restrain the reaction. For example, cyclohexene was completely unconverted when using the high $\mathrm{Al}$ content catalyst AP-Si/Ti-MCM-36, but with A-Si/Ti-MCM-36, which had a lower Al content, it was converted in 38\% yield and gave $\mathbf{2}$ and $\mathbf{3}$ with a high total selectivity (Table 2, entries 2 and 3) [36]. Different from $\mathrm{Ti}$, the molecular sieve-supported $\mathrm{Cr}$ catalyst (Cr-MCM-48) was more effective for allylic C-H oxidation and provided cyclohex-2-en-1-one 6 as the major product (Table 2, entry 4) [37]. Easily prepared and separated $\mathrm{Fe}_{3} \mathrm{O}_{4}$ magnetic nanoparticles (MNPs) could also catalyze the oxidation under solvent-free conditions and produced 6 in a good isolated yield (Table 2, entry 5) [38]. The reaction catalyzed by nano-CuO provided a good cyclohexene conversion and cyclohex-2-en-1-one 6 selectivity, and the catalyst was further improved when supported on halloysite nanotubes (HNTs), affording cyclohex-2-en-1-one $\mathbf{6}$ in an excellent yield (Table 2, entries 7 vs. 6) [39]. Cobalt(II) alkyl phosphonate-modified silica (CoEPS3) was a nice catalyst for allylic $\mathrm{C}$ - $\mathrm{H}$ oxidation with $t$-BuOOH and produced 6 in a very high isolated yield (Table 2 , entry 8) [40]. Ag-doped vanadium phosphorus oxide (Ag-VPO) was also a good allylic $\mathrm{C}-\mathrm{H}$ oxidation catalyst that led to a high reaction conversion and selectivity (Table 2, entry 9) [41]. The catalyst could be recycled and reused without deactivation (Table 2, entry 10) [41]. Au-catalyzed reactions were also investigated, and the catalyst was supported on silica monolith

\section{Table 2}

Oxidation of cyclohexene by $t$-BuOOH catalyzed by supported/heterogeneous catalyst a.

\begin{tabular}{lccc}
\hline Entry & Catalyst & Product (yield) ${ }^{\mathrm{b}}$ & Ref. \\
\hline 1 & A-40Si/Ti-MCM-36(E) & $\mathbf{2}(58 \%)$ & {$[35]$} \\
2 & AP-Si/Ti-MCM-36 & - & {$[36]$} \\
3 & A-Si/Ti-MCM-36 & $\mathbf{2}(84 \% \times 38 \%), \mathbf{3}(11 \% \times 38 \%)$, & {$[36]$} \\
& & $\mathbf{5}(3 \% \times 38 \%), \mathbf{6}(1 \% \times 38 \%)$ & \\
4 & Cr-MCM-48 & $\mathbf{6}(83 \% \times 67 \%)$ & {$[37]$} \\
5 & $\mathrm{Fe}_{3} \mathrm{O}_{4}$ MNPs & $\mathbf{6}(87 \%)$ & {$[38]$} \\
6 & Nano-CuO & $\mathbf{6}(82 \% \times 84 \%)$ & {$[39]$} \\
7 & Nano-CuO/HNTs & $\mathbf{6}(98 \% \times 99 \%)$ & {$[39]$} \\
8 & CoEPS3 & $\mathbf{6}(90 \%)$ & {$[40]$} \\
9 & Ag-VPO & $\mathbf{6}(89 \% \times 97 \%)$ & {$[41]$} \\
10 & Ag-VPO (recycled) & $\mathbf{6}(89 \% \times 96 \%)$ & {$[41]$} \\
11 & Au/monolith & $\mathbf{2}(30 \% \times 3 \%), \mathbf{5}(52 \% \times 3 \%)$, & {$[42]$} \\
& (impregnated) & $\mathbf{6}(18 \% \times 3 \%)$ & \\
12 & Au/monolith & $\mathbf{2}(3 \% \times 18 \%), \mathbf{5}(16 \% \times 18 \%)$, & {$[42]$} \\
& (thiol modified) & $\mathbf{6}(82 \% \times 18 \%)$ \\
\hline
\end{tabular}

${ }^{a}$ For detailed reaction conditions, please see the original references. ${ }^{\mathrm{b}}$ Yield in $\mathrm{A} \times \mathrm{B}$ form: $\mathrm{A}=$ product selectivity, $\mathrm{B}=$ cyclohexene conversion. 
microreactors. After thiol modification, both the cyclohexene convention and hex-2-en-1-one 6 selectivity were largely improved (Table 2, entries 12 vs. 11) [42]. The reactions were tested with $\mathrm{H}_{2} \mathrm{O}_{2}$ as a cleaner oxidant, but the cyclohexene conversion dramatically decreased ( $3 \%$ vs. $18 \%$ with $t$ - $\mathrm{BuOOH})$ [42]. Besides traditional catalysts, the reactions with novel catalytic materials, such as metal-organic frameworks (MOFs) or graphitic carbon nitride $\left(g-\mathrm{C}_{3} \mathrm{~N}_{4}\right)$-supported nanoparticles (NPs), have drawn much attention in recent years [43-46].

\section{Oxidation using $\mathrm{H}_{2} \mathrm{O}_{2}$}

Hydrogen peroxide is a common oxidant. It affords no waste other than water after the reaction, and it is cheaper than $t$-BuOOH. Therefore, from an industrial viewpoint, $\mathrm{H}_{2} \mathrm{O}_{2}$ is a good oxidant because of its green features and low cost. In the field of cyclohexene oxidation, reactions with $\mathrm{H}_{2} \mathrm{O}_{2}$ as the oxidant have received comprehensive attention. A series of metal catalysts, including $\mathrm{W}, \mathrm{Mn}, \mathrm{V}, \mathrm{Cr}, \mathrm{Co}, \mathrm{Fe}, \mathrm{Cu}, \mathrm{Ni}, \mathrm{Bi}, \mathrm{Os}$, and rare metals, have been applied. Metal-free catalysts, such as organocatalysts, are also effective for the transformation.

Tungsten-catalyzed oxidation of cyclohexene is of great value for industrial applications because it is inexpensive and offers a high product yield. Catalyzed by $\mathrm{H}_{2} \mathrm{WO}_{4}$ and in the presence of $\mathrm{H}_{3} \mathrm{PO}_{4}$ and a phase-transfer agent (PTA), the oxidation of cyclohexene with $\mathrm{H}_{2} \mathrm{O}_{2}$ led to trans-diol 3 in excellent yield (Table 3, entry 1) [47]. Notably, with the same catalyst system and oxidant, the diol could be further oxidized to adipic acid 4, which is a very useful intermediate in nylon-66 production [47]. The sandwich-type polyoxometalate (POM) tungsten catalysts were designed and tested for cyclohexene oxidation: For example, catalyzed by $\mathrm{TBA}_{10}\left[\mathrm{Zn}_{4}\left(\mathrm{PW}_{9} \mathrm{O}_{34}\right)_{2}\right]$, the oxidation of cyclohexene with $\mathrm{H}_{2} \mathrm{O}_{2}$ led to epoxide 2 as the major product at $50{ }^{\circ} \mathrm{C}$ (Table 3 , entry 2) [48]. The reaction selectivity was dramatically enhanced by decreasing the reaction temperature, albeit with a decreased cyclohexene conversion ratio (Table 3, entry 3) [48]. The POM-based stable polymeric hybrid POSS-OIM 8 -PW could be prepared using polyhedral oligomeric vinylsilsesquioxanes (POSSs) and ionic liquids (ILs) bearing hydrophobic alkyl chains as the building blocks, followed by ion exchange with Keggin-type phosphotungstic acid (PW), and it possessed good catalytic activities to produce epoxide $\mathbf{2}$ (Table 3 , entry 4) [49]. The recyclable heterogeneous catalytic assembly of $\left[\mathrm{PO}_{4}\left\{\mathrm{WO}\left(\mathrm{O}_{2}\right)_{2}\right\}_{4}\right]^{3-}$ in the IL brush was also developed to produce diol 3 in almost quantitative yield (Table 3, entry 5) [50].

Manganese catalysts were also employed in the oxidation of cyclohexene by $\mathrm{H}_{2} \mathrm{O}_{2}$. Gültekin et al. [51] found that, with a 0.5 equivalent of $\mathrm{KMnO}_{4}$, the oxidation reaction of cyclohexene by $\mathrm{H}_{2} \mathrm{O}_{2}$ afforded diol 3 in $95 \%$ yield at $0{ }^{\circ} \mathrm{C}$ in $\mathrm{N}_{2}$ (Table 3, entry 6). The product yield decreased at room temperature or without $\mathrm{N}_{2}$ protection, and the manganese oxide NPs generated in situ were likely the catalytic species [51]. Louloudi et al. [52] developed Mn-non-heme catalysts 15a-b for the epoxidation of cyclohexene with $\mathrm{H}_{2} \mathrm{O}_{2}$, which was much more active than homologous Fe catalysts 15c-d (Fig. 3 and Table 3, entries 7 and 8 vs. 9 and 10). The supported Mn complexes were reported as
Table 3

Oxidation of cyclohexene by $\mathrm{H}_{2} \mathrm{O}_{2}$ with a metal catalyst a.

\begin{tabular}{|c|c|c|c|}
\hline Entry & Metal catalyst & Product (yield) ${ }^{\mathrm{b}}$ & Ref. \\
\hline 1 & $\mathrm{H}_{2} \mathrm{WO}_{4} / \mathrm{H}_{3} \mathrm{PO}_{4} / \mathrm{PTA}$ & $3(97 \%)$ & [47] \\
\hline 2 & $\begin{array}{c}\mathrm{TBA}_{10}\left[\mathrm{Zn}_{4}\left(\mathrm{PW}_{9} \mathrm{O}_{34}\right)_{2}\right] \\
\left(50^{\circ} \mathrm{C}\right)\end{array}$ & $\begin{array}{c}2(80 \% \times 88 \%), 5(5 \% \times 88 \%), 6 \\
(15 \% \times 88 \%)\end{array}$ & [48] \\
\hline 3 & $\begin{array}{c}\mathrm{TBA}_{10}\left[\mathrm{Zn}_{4}\left(\mathrm{PW}_{9} \mathrm{O}_{34}\right)_{2}\right] \\
\left(25^{\circ} \mathrm{C}\right)\end{array}$ & $2(99 \% \times 66 \%), 6(1 \% \times 66 \%)$ & [48] \\
\hline 4 & 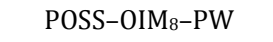 & $2(94 \% \times 93 \%)$ & [49] \\
\hline 5 & {$\left[\mathrm{PO}_{4}\left\{\mathrm{WO}\left(\mathrm{O}_{2}\right)_{2}\right\}_{4}\right]^{3-} / \mathrm{IL}$} & 3 (99\%) & [50] \\
\hline 6 & $\mathrm{KMnO}_{4}$ & $3(95 \%)$ & {$[51]$} \\
\hline 7 & 15a $\left[\mathrm{LMn}(\mathrm{OAc})_{2}\right]$ & 2 (61\%), 5 (4\%), 6 (2\%) & [52] \\
\hline 8 & $\mathbf{1 5 b}\left(\mathrm{LMnCl}_{2}\right)$ & $2(53 \%), 5(2 \%), 6(2 \%)$ & [52] \\
\hline 9 & 15c $\left[\mathrm{LFe}(\mathrm{OAc})_{2}\right]$ & 2 (3\%), 5 (10\%), 6 (13\%) & [52] \\
\hline 10 & 15d $\left(\mathrm{LFeCl}_{2}\right)$ & 2 (3\%), 5 (8\%), 6 (9\%) & [52] \\
\hline 11 & 16a $\left[\mathrm{LFe}\left(\mathrm{NO}_{3}\right)\right]$ & $\begin{array}{c}2(12 \% \times 86 \%), 3(12 \% \times 86 \%) \\
\mathbf{5}(35 \% \times 86 \%), 6(41 \times 86 \%)\end{array}$ & [55] \\
\hline 12 & 16b $\left[\mathrm{LFe}\left(\mathrm{NO}_{3}\right)\right]$ & $\begin{array}{c}2(11 \% \times 71 \%), 3(8 \% \times 71 \%) \\
\mathbf{5}(38 \% \times 71 \%), 6(42 \times 71 \%)\end{array}$ & [55] \\
\hline 13 & 16c (LRuCl) & $\begin{array}{c}2(13 \% \times 98 \%), 3(5 \% \times 98 \%) \\
\mathbf{5}(32 \% \times 98 \%), 6(50 \times 98 \%)\end{array}$ & [55] \\
\hline 14 & 16d (LRuCl) & $\begin{array}{c}2(11 \% \times 82 \%), 3(10 \% \times 82 \%), \\
\mathbf{5}(33 \% \times 82 \%), 6(46 \times 82 \%)\end{array}$ & [55] \\
\hline 15 & $17\left(\mathrm{VOTPPCl}_{8}\right)$ & $2(99 \% \times 100 \%)$ & [56] \\
\hline 16 & Cr-MCM-41 & $6(100 \% \times 47 \%)$ & [59] \\
\hline 17 & $\mathrm{Cr}-\mathrm{mZrP}$ & $6(100 \% \times 63 \%)$ & [60] \\
\hline 18 & $\mathrm{CoCr}-\mathrm{HTSi}_{2}$ & $6(74 \% \times 99 \%)$ & [62] \\
\hline 19 & Co-salen-SBA-15 & $\begin{array}{c}2(80 \% \times 75 \%) \text { or } \mathbf{5}(85 \% \times 80 \%) \\
\text { or } \mathbf{6}(89 \% \times>99 \%)\end{array}$ & [63] \\
\hline 20 & CFO-Ce0.3 & $\begin{array}{c}2(3 \% \times 49 \%), 5(32 \% \times 49 \%) \\
6(54 \% \times 49 \%)\end{array}$ & [64] \\
\hline 21 & $\mathrm{MC}-\mathrm{OsO}_{4}$ & $3(96 \%)$ & [66] \\
\hline 22 & 18 & $3(98 \%)$ & [67] \\
\hline
\end{tabular}

a,b See Table 2 .
(1)

15a: $\mathrm{M}=\mathrm{Mn}, \mathrm{X}=\mathrm{OAc}$ 15b: $\mathrm{M}=\mathrm{Mn}, \mathrm{X}=\mathrm{Cl}$ 15c: $\mathrm{M}=\mathrm{Fe}, \mathrm{X}=\mathrm{OA}$ 15d: $\mathrm{M}=\mathrm{Fe}, \mathrm{X}=\mathrm{Cl}$

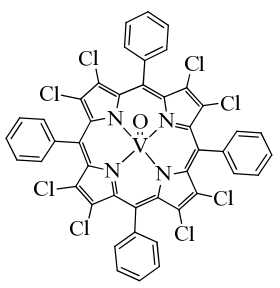

17

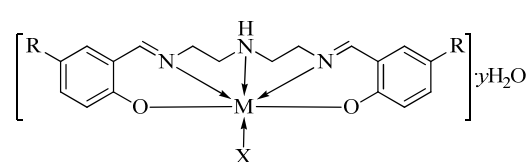

16a: $\mathrm{M}=\mathrm{Fe}$ (III), $\mathrm{R}=\mathrm{H}, \mathrm{X}=\mathrm{NO}_{3}, y=2$ 16b: $\mathrm{M}=\mathrm{Fe}(\mathrm{III}), \mathrm{R}=\mathrm{NO}_{2}, \mathrm{X}=\mathrm{NO}_{3}, y=2$ 16c: $\mathrm{M}=\mathrm{Ru}(\mathrm{III}), \mathrm{R}=\mathrm{H}, \mathrm{X}=\mathrm{Cl}, y=1$ 16d: $\mathrm{M}=\mathrm{Ru}$ (III), $\mathrm{R}=\mathrm{NO}_{2}, \mathrm{X}=\mathrm{Cl}, y=1$

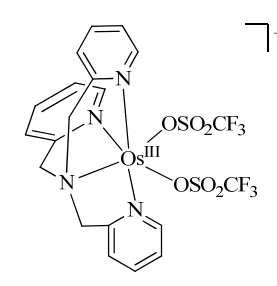

18
Fig. 3. Metal complexes employed in cyclohexene oxidation by $\mathrm{H}_{2} \mathrm{O}_{2}$.

heterogeneous catalysts by the same group the next year [53,54]. Godhani et al. [55] designed and prepared a series of Schiff base-coordinated Fe and Ru complexes 16a-d for cyclohexene oxidation with $\mathrm{H}_{2} \mathrm{O}_{2}$ (Fig. 3), and the $\mathrm{Ru}$ complexes were better catalysts than the Fe complexes (Table 3, entries 13 and 14 vs. 11 and 12). The complexes could be uploaded 
onto zeolite-Y to develop recyclable heterogeneous catalysts [55]. Electron-deficient nonplanar $\beta$-octachlorovanadylporphyrin 17 (VOTPPCl 8 ) was an efficient catalyst for cyclohexene epoxidation with $\mathrm{H}_{2} \mathrm{O}_{2}$, giving an almost quantitative yield of $\mathbf{2}$ with a full conversion of cyclohexene (Table 3, entry 15) [56]. The dioxidovanadium( $(\mathrm{V})$ complexes with thiazol-hydrazone as the NNN-donor ligands for cyclohexene epoxidation were also reported [57]. Like $\mathrm{Fe}$ and $\mathrm{Ru}$, the $\mathrm{V}$ complexes could be uploaded onto zeolite- $Y$ to fabricate recyclable and reusable heterogeneous catalysts [58].

Cr-catalyzed cyclohexene oxidation with $\mathrm{H}_{2} \mathrm{O}_{2}$ occurred at the allylic $\mathrm{C}-\mathrm{H}$ site. When catalyzed by the Cr-MCM- 41 mesoporous molecular sieves, cyclohex-2-en-1-one 6 was exclusively produced (Table 3, entry 16) [59]. The cyclohexene conversion ratio was enhanced using mesoporous zirconium phosphate (mZrP) as the support (Table 3, entry 17) [60]. The silica-supported $\mathrm{Cr}$ complexes as heterogeneous catalysts were also reported in the field, and both $\mathbf{5}$ and $\mathbf{6}$ were generated simultaneously [61]. By introducing cobalt, the silicate intercalated cobalt chromium-hydrotalcite catalyst ( $\mathrm{CoCr}-\mathrm{HTSi}_{2}$ ) enhanced the conversion ratio of cyclohexene but reduced the selectivity of 6 (Table 3, entry 18) [62]. Indeed, Co could catalyze the reaction independently. For example, in 2008, Clark et al. [63] reported microwave-assisted oxidation of cyclohexene with $\mathrm{H}_{2} \mathrm{O}_{2}$ catalyzed by a supported Co complex (Co-salen-SBA-15). The oxidation process could be controlled to selectively produce 2,5 , or $\mathbf{6}$ using different reaction conditions (Table 3, entry 19) [63]. Tong et al. [64] reported cerium-doped cobalt ferrite nanocrystals (CFO-Ce0.3) for cyclohexene oxidation, which produced $\mathbf{5}$ and $\mathbf{6}$ as the major products, and about half of the cyclohexene was converted (Table 3, entry 20). A magnetic Co material was also developed to easily recycle the catalyst [65].

$\mathrm{OsO}_{4}$ is an efficient oxidant that can lead to cis-diol in very high yield in an alkene oxidation reaction. However, because of its high price and toxicity, the application scope of this reaction is limited to large-scale production when using a clean oxidant with $\mathrm{OsO}_{4}$ as the catalyst instead of the oxidant. In 2006, a recyclable and reusable microencapsulated $\mathrm{OsO}_{4}$ catalyst $\left(\mathrm{MC}-\mathrm{OsO}_{4}\right)$ was invented, which could catalyze the oxidation reaction of cyclohexene with $\mathrm{H}_{2} \mathrm{O}_{2}$ to produce diol 3 in $96 \%$ isolated yield (Table 3, entry 21) [66]. Sugimoto et al. [67] designed a series of macrocyclic Os complexes, such as $\mathbf{1 8}$ (Fig. 3), that could catalyze the reaction to produce cis-diol $\mathbf{3}$ in excellent yield (Table 3, entry 22). These complexes are so active that the catalyst turnover number (TON) can be up to 5500 [68]. Hydrotalcite- and dendrimer-supported Os catalysts were also developed [69-72]. Besides the above examples, other transition metals, such as Mo [73], $\mathrm{Cu}$ [74-76], $\mathrm{Ni}$ [77], $\mathrm{Bi}$ $[78,79]$, Ti [80], and rare earth metals [81-83], could also catalyze the oxidation reactions of cyclohexene with $\mathrm{H}_{2} \mathrm{O}_{2}$ as the oxidant.

The reaction was also catalyzed by non-metal catalysts. In 2003, Sato et al. [84] reported that the oxidation of cyclohexene with $\mathrm{H}_{2} \mathrm{O}_{2}$ and catalyzed by immobilized sulfonic acid produced trans-diol 3 in 98\% yield. The method did not require any organic solvents or metal catalysts, and thus was very clean for large-scale applications [84]. Latter, Afonso et al. [85] investigated the catalytic activities of a series of Brønsted acids in the dihydroxy reaction of cyclohexene to trans-diol $\mathbf{3}$, and $p$-toluenesulfonic acid was identified as the best catalyst, affording 3 in up to $98 \%$ yield. Organocatalysis afforded much milder reaction conditions for the transformation, and Kokotos et al. [86] found that $\mathrm{H}_{2} \mathrm{O}_{2}$ could oxidize alkenes to produce diols when catalyzed by 2,2,2-trifluoroacetophenone. In cyclohexene oxidation, trans-diol 3 was produced in $96 \%$ yield.

We found that organoselenium compounds were good catalysts for cyclohexene oxidation with $\mathrm{H}_{2} \mathrm{O}_{2}$ to produce trans-diol 3. Catalyzed by (PhSe)2, the reaction at $30{ }^{\circ} \mathrm{C}$ led to 3 in $96 \%$ yield after $42 \mathrm{~h}$ [15]. The reaction was accelerated using $\left[3,5-\left(\mathrm{CF}_{3}\right)_{2} \mathrm{C}_{6} \mathrm{H}_{3} \mathrm{Se}\right]_{2}$ as a catalyst, and it was completed within 3-5 h [16]. Immobilizing the Se catalyst onto the polymers facilitated the recovery process of the catalyst and reduced the amount of $\mathrm{H}_{2} \mathrm{O}_{2}$ because the highly active hexavalent Se species could be well stabilized on polymers to catalyze the reaction more efficiently. The reaction could even use air as the independent oxidant to produce 3 in 18\% yield [17].

\section{Oxidation using molecular oxygen}

Although $\mathrm{H}_{2} \mathrm{O}_{2}$ is a green oxidant that produces no waste other than water, it is an explosive chemical that may be very dangerous for large scale production. Moreover, the price of $\mathrm{H}_{2} \mathrm{O}_{2}$ is somewhat high for producing basic chemicals. Therefore, for a long period, much attention has been devoted to developing cyclohexene oxidation reactions using molecular oxygen as a cheap and safe oxidant.

Early in 1993, Alper et al. [87] reported a $\mathrm{CoCl}_{2}$-catalyzed, $\mathrm{N}$-methylpyrrolidinone (NMP)-assisted allylic oxidation of cyclohexene with molecular oxygen to produce cyclohex-2-en-1-one 6 in 66\% yield (Table 4, entry 1). The reaction could be improved using a Co-based IL $\left\{\left[\mathrm{C}_{10 \mathrm{mim}}\right]\right.$ [Co( $\mathrm{F}_{6}$-acac) $\left.\left.)_{3}\right]\right\}$ (Table 4, entry 2) [88]. The reaction with the cobalt- $L$-glutamic acid complex catalyst led to an $83 \%$ cyclohexene conversion and generated 2, 5, and $\mathbf{6}$ in 93\% total selectivity (Table 4 , entry 3). In the process, the amino acid-coordinated $\mathrm{Co}(\mathrm{II})$ was first oxidized by $\mathrm{O}_{2}$ to generate $\mathrm{Co}(\mathrm{III}) 00$ species, which oxidized the allylic $\mathrm{C}$ - $\mathrm{H}$ of cyclohexene to produce the allylic peroxide alcohol. The reaction of peroxide alcohol with another molecule of cyclohexene afforded epoxide $\mathbf{2}$ and allylic alcohol 5, which could be further oxidized to allylic ketone 6 [89]. Catalyzed by $g$ - $\mathrm{C}_{3} \mathrm{~N}_{4}$-supported Co, $56 \%$ of cyclohexene was converted in the oxidation reaction, and $\mathbf{5}$ and $\mathbf{6}$ were obtained in $23 \%$ and $72 \%$ selectivities, respectively (Table 4, entry 4) [90]. By doping Fe into the catalyst (Fe/Co = 5/1), the generation of 5 was depressed to give 6 with an excellent selectivity, albeit with a decreased cyclohexene conversion ratio (Table 4, entry 5) [90]. Nam et al. [91] designed and prepared an Fe(V)-oxo complex 19 (Fig. 4), which could catalyze the cyclohexene oxidation reaction in the $\mathrm{O}_{2}$-saturated MeCN solvent to produce 6 exclusively (Table 4, entry 6). The catalyst amount and cyclohexene initial concentration were key factors to control the reaction product selectivity [91]. The Fe complex of meso-tetrakisphenyl porphyrin was a good catalyst 
Table 4

Oxidation of cyclohexene by molecular oxygen with a transition-metal catalyst ${ }^{\mathrm{a}}$.

\begin{tabular}{|c|c|c|c|}
\hline$\overline{\text { Entry }}$ & Metal catalyst & Product (yield) ${ }^{b}$ & Ref. \\
\hline 1 & $\mathrm{CoCl}_{2} / \mathrm{NPM}$ & $6(66 \%)$ & {$[87]$} \\
\hline 2 & {$\left[\mathrm{C}_{10} \mathrm{mim}\right]\left[\mathrm{Co}\left(\mathrm{F}_{6}-\mathrm{acac}\right)_{3}\right]$} & $6(81 \% \times 100 \%)$ & [88] \\
\hline 3 & Co- $L$-glutamic acid & $\mathbf{2 + 5 + 6}(93 \% \times 83 \%)$ & [89] \\
\hline 4 & Co- $g-\mathrm{C}_{3} \mathrm{~N}_{4}$ & $\begin{array}{c}3(2 \% \times 56 \%), 5(23 \% \times 56 \%) \\
6(72 \% \times 56 \%)\end{array}$ & [90] \\
\hline 5 & 5-Fe-Co- $g-\mathrm{C}_{3} \mathrm{~N}_{4}$ & $\begin{array}{c}3(2 \% \times 22 \%), 5(1 \% \times 22 \%) \\
6(96 \% \times 22 \%)\end{array}$ & {$[90]$} \\
\hline 6 & $19\left\{\left[(\mathrm{TAML}) \mathrm{Fe}^{\mathrm{III}}\right]-\right\}$ & $6(89 \%)$ & [91] \\
\hline 7 & $\mathrm{Fe}(\mathrm{TPP}) \mathrm{Cl} /$ chloramine- $\mathrm{T}$ & $6(52 \%)$ & {$[92]$} \\
\hline 8 & 20 (NSP) & $5(57 \% \times 49 \%), 6(43 \% \times 49 \%)$ & [93] \\
\hline 9 & NSP-MWNTs & $5(72 \% \times 69 \%), 6(28 \% \times 69 \%)$ & [93] \\
\hline 10 & np-Au-silica & $5(3 \% \times 92 \%), 6(97 \% \times 92 \%)$ & {$[94]$} \\
\hline 11 & np- $\mathrm{Au}(\mathrm{Ag})-\mathrm{MeOH}$ & $\mathbf{2 + 5 + 6}(81 \% \times 11 \%)$ & [95] \\
\hline 12 & np-Ag-MCM-41 & $\begin{array}{c}2(3 \% \times>99 \%), 5 \\
(25 \% \times>99 \%), 6(68 \% \times>99 \%)\end{array}$ & [96] \\
\hline 13 & $\mathrm{BNO}_{2}-\mathrm{Cu}-\mathrm{TDCPP}$ & $\begin{array}{l}5(21 \% \times>66 \%) \\
6(69 \% \times>66 \%)\end{array}$ & [97] \\
\hline 14 & np-CuO-PVA- $\mathrm{Fe}_{3} \mathrm{O}_{4}$ & $\begin{array}{c}2(4 \% \times 76 \%), 5(35 \% \times 76 \%) \\
\mathbf{6}(61 \% \times 76 \%)\end{array}$ & [98] \\
\hline 15 & [Cu-imace-H-H] $\left[\mathrm{BF}_{4}\right]$ & $\begin{array}{c}2(82 \% \times 99 \%), 5(2 \% \times 99 \%) \\
6(11 \% \times 99 \%)\end{array}$ & [99] \\
\hline 16 & $\mathrm{Mn}(\mathrm{TCPP}) \mathrm{Cl}$-tart $-\mathrm{Fe}_{3} \mathrm{O}_{4}$ & $2(86 \% \times 98 \%), 5(12 \% \times 98 \%)$ & {$[100]$} \\
\hline 17 & Mn-TS-1 & $\begin{array}{c}2(4 \% \times 28 \%), 5(29 \% \times 28 \%) \\
6(62 \% \times 28 \%)\end{array}$ & [101] \\
\hline 18 & CdS flowers & $6(100 \% \times 75 \%)$ & [102] \\
\hline 19 & $\begin{array}{l}\mathrm{Mo}(\mathrm{VI}) \mathrm{Cl}_{2} \mathrm{O}_{2} \mathrm{Bipy}^{-\mathrm{TiO}_{2}} \\
\mathrm{SC}-150\end{array}$ & 2 (45\%), 5 (4\%), 6 (5\%) & [103] \\
\hline 20 & $\begin{array}{l}\mathrm{Mo}(\mathrm{VI}) \mathrm{Cl}_{2} \mathrm{O}_{2} \mathrm{Bipy}-\mathrm{TiO}_{2} \\
\mathrm{SC}-150 \text { (recycled) }\end{array}$ & 2 (40\%), 5 (4\%), 6 (7\%) & [103] \\
\hline
\end{tabular}

a,b See Table 2.

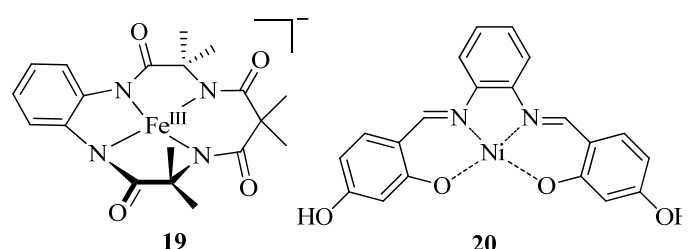

Fig. 4. Metal complexes employed for cyclohexene oxidation by molecular oxygen.

for allylic oxidation with molecular oxygen in the presence of chloramine-T; although the reactions of some substrates, such as tertralin, diphenyl methane, and $9 H$-fluorene, afforded the related ketones in good yields ( $>80 \%$ ), the oxidation of cyclohexene produced 6 in only 52\% yield (Table 4, entry 7) [92]. Nickel complexes, such as Schiff base-coordinated Ni 20 (Fig. 4), also served as active catalysts in cyclohexene oxidation with molecular oxygen to produce 5 and $\mathbf{6}$, while $49 \%$ of cyclohexene was converted (Table 4, entry 8) [93]. By binding complex 20 onto multi-wall carbon nanotubes (MWNTs), both the cyclohexene conversion ratio and the alcohol selectivity were enhanced (Table 4, entry 9) [93].

Coinage metals, such as gold, silver, and copper, were also employed in the reactions. Au NPs on silica (np-Au-silica) as a catalyst led to excellent conversion of cyclohexene to produce $\mathbf{5}$ (3\% selectivity) and 6 ( $97 \%$ selectivity), while no other by-products were detected (Table 4, entry 10) [94]. The nanoporous $\mathrm{Au}$ with minor $\mathrm{Ag}$ content could also catalyze the reaction, albeit with a decreased cyclohexene conversion and product selectivity (Table 4, entry 11) [95]. Catalyzed by Ag NPs on MCM-41, more than $99 \%$ of the cyclohexene was converted to produce $\mathbf{2}, \mathbf{5}$, and $\mathbf{6}$ in an excellent total selectivity of $96 \%$ (Table 4, entry 12). The reaction was initiated by catalytic $t$-BuOOH [96]. Since copper is much cheaper than gold and silver, using the $\mathrm{Cu}$ catalyst largely reduces the cost and is of great industrial application meanings. In 2016, Calvete et al. [97] developed a magnetically recyclable $\mathrm{Cu}$ porphyrinic catalyst $\left(\mathrm{BNO}_{2}-\mathrm{Cu}\right.$-TDCPP) for the reaction, affording $\mathbf{5}$ and $\mathbf{6}$ (Table 4 , entry 13 ). The magnetically recoverable CuO NPs could also catalyze the reaction with an enhanced cyclohexene conversion and allylic oxidation product selectivity (Table 4, entry 14) [98]. Using recyclable copper catalysts with an imidazole salt tag (e.g., [Cu-imace-H-H] $\left.\left[\mathrm{BF}_{4}\right]\right), 99 \%$ of the cyclohexene was converted to produce epoxide $\mathbf{2}$ as the overwhelming major product (Table 4, entry 15). The reaction employs an extremely low amount of the catalyst (part per million level) and thus results in a very high TON of the catalyst [99].

The reaction catalyzed by the magnetically recoverable Mn-porphyrin catalyst also led to epoxide $\mathbf{2}$ as the major product, while $98 \%$ of cyclohexene was converted (Table 4, entry 16) [100]. Differently, reacting with the Mn-containing hollow framework catalyst was predominant via the allylic oxidation route (Table 4 , entry 17) [101]. Catalyzed by an ultrathin $(0.8$ $\mathrm{nm}$ ) sheet mediated uniform CdS flowers, only $\mathbf{6}$ was produced, while $75 \%$ of cyclohexene was converted (Table 4, entry 18) [102]. A $\mathrm{TiO}_{2}$-supported Mo-complex-catalyzed photo reaction afforded epoxide $\mathbf{2}$ as the major product, and the catalyst was recovered without deactivation (Table 4, entries 19 and 20) [103].

Non-transition-metal-catalyzed oxidations of cyclohexene with molecular oxygen were also reported. In 1980, Tempesti et al. [104] found that cyclohexene was oxidized to 6 (catalyzed by $\mathrm{KOAc}$ and induced by $\mathrm{SO}_{2}$ ) in $67 \%$ yield under pressured $\mathrm{O}_{2}$ (10 atm) and $\mathrm{N}_{2}(100 \mathrm{~atm})$ (Table 5, entry 1). The reaction was also catalyzed by $N$-hydroxyphthalimide (NHPI) with alkaline-earth chlorides, such as $\mathrm{MgCl}_{2}$ (Table 5, entry 2) [105]. The $g$ - $\mathrm{C}_{3} \mathrm{~N}_{4} / \mathrm{NHPI}$ system-catalyzed reaction at $130^{\circ} \mathrm{C}$ to produce 6 was also reported (Table 5, entry 3) [106]. Irradiated by visible light, the reaction could smoothly occur at $60^{\circ} \mathrm{C}$ at an elevated

Table 5

Oxidation of cyclohexene by molecular oxygen with a non-transition-metal catalyst a.

\begin{tabular}{lccc}
\hline Entry & Non-metal catalyst & Product (yield) ${ }^{\mathrm{b}}$ & Ref. \\
\hline 1 & $\mathrm{KOAc} / \mathrm{HOAc} / \mathrm{SO}_{2}$ & $\mathbf{6}(67 \%)$ & {$[104]$} \\
2 & $\mathrm{MgCl}_{2} / \mathrm{NHPI}$ & $\mathbf{6}(67 \% \times 90 \%)$ & {$[105]$} \\
3 & $g$ - $\mathrm{C}_{3} \mathrm{~N}_{4} / \mathrm{NHPI}\left(130{ }^{\circ} \mathrm{C}\right)$ & $\mathbf{6}(82 \% \times 65 \%)$ & {$[106]$} \\
4 & $g$ - $\mathrm{C}_{3} \mathrm{~N}_{4} / \mathrm{NHPI}($ visible light irradi- & $\mathbf{6}(77 \% \times 93 \%)$ & {$[107]$} \\
& ation, $\left.60{ }^{\circ} \mathrm{C}\right)$ & & \\
5 & $g-\mathrm{C}_{3} \mathrm{~N}_{4} / \mathrm{NHPI}($ recycled, visible & $\mathbf{6}(71 \% \times 92 \% ;$ & {$[107]$} \\
& light irradiation, $\left.60^{\circ} \mathrm{C}\right)$ & $66 \% \times 90 \% ; 67 \% \times 95 \%)$ & \\
\hline
\end{tabular}

a,b See Table 2. 
cyclohexene conversion (Table 5, entry 4), and the catalyst could be recycled and reused at least three times (Table 5, entry 5) [107]. The carbon nanodot-doped $g-\mathrm{C}_{3} \mathrm{~N}_{4}$ catalyst was recently reported for the reaction to produce 6 [108]. Reactions catalyzed by nitrogen-doped carbon nanotubes were also investigated, but led to $2, \mathbf{3}, \mathbf{4}$, and $\mathbf{5}$ in poor selectivities, while 3-hydroperoxycyclohex-1-ene was obtained as the major product [109].

\section{Conclusions}

In summary, the selectivity of the oxidation reaction of cyclohexene can be affected by the catalyst and reaction conditions, such as the solvent, temperature, catalyst loading, and oxidant. By evaluating these parameters and optimizing the reaction conditions, the oxidation of cyclohexene might be controlled to occur at its allylic $\mathrm{C}-\mathrm{H}$ site or $\mathrm{C}=\mathrm{C}$ bond site, which would then lead to selective production of 7-oxabicyclo[4.1.0] heptane 2, trans/cis-cyclohexane-1,2-diol 3, adipic acid 4, cyclohex-2-en-1-ol 5, or cyclohex-2-en-1-one 6 as the major product. Various oxidants, such as $t-\mathrm{BuOOH}, \mathrm{H}_{2} \mathrm{O}_{2}$, or molecular oxygen $\left(\mathrm{O}_{2}\right)$, can be employed as the oxidant of the reaction. Among the oxidants, $\mathrm{O}_{2}$ (or even air) is clearly the most ideal oxidant for the reaction because of its low cost, practicality in use, and waste-free feature (i.e., generating water as the only byproduct). However, this area is still rapidly developing. More novel and practical new techniques, such as electrocatalytic methods $[110,111]$, have recently emerged as a new selective methods in this area.

\section{Acknowledgments}

We thank Dr. Kehong Ding (Jiangsu Yangnong Chemical Group Co. Ltd.) for his kind suggestions.

\section{References}

[1] Z. B. Wang, Q. Zhang, X. F. Lu, S. J. Chen, C. J. Liu, Chin. J. Catal., 2015, 36, 400-407.

[2] G. B. Zhou, R. F. Dou, H. Z. Bi, S. H. Xie, Y. Pei, K. N. Fan, M. H. Qiao, B. Sun, B. N. Zong, J. Catal., 2015, 332, 119-126.

[3] H. J. Sun, Y. J. Pan, S. H. Li, Y. X. Zhang, Y. Y. Dong, S. C. Liu, Z. Y. Liu, J. Energy. Chem., 2013, 22, 710-716.
[4] Z. L. Li, A. Lv, L. Li, X. X. Deng, L. J. Zhang, F. S. Du, Z. C. Li, Polymer, 2013, 54, 3841-3849.

[5] S. C. Dakdouki, D. Villemin, N. Bar, Eur. J. Org. Chem., 2011, 2011, 4448-4454.

[6] O. Cussó, M. Cianfanelli, X. Ribas, R. J. M. K. Gebbink, M. Costas, J. Am. Chem. Soc., 2016, 138, 2732-2738

[7] J. S. Li, Z. Qiu, C. J. Li, Adv. Synth. Catal., 2017, 359, 3648-3653.

[8] D. L. Zhang, Z. Wei, L. Yu, Sci. Bull., 2017, 62, 1325-1330.

[9] Y. G. Wang, Z. L. Wu, Q. Li, B. C. Zhu, L. Yu, Catal. Sci. Technol., 2017, 7, 3747-3757.

[10] L. Yu, Z. Han, Y. H. Ding, Org. Process. Res. Dev., 2016, 20, 2124-2129.

[11] S. C. Deng, T. T. Meng, B. L. Xu, F. Gao, Y. H. Ding, L. Yu, Y. N. Fan, ACS Catal., 2016, 6, 5807-5815.

[12] T. T. Wang, X. B. Jing, C. Chen, L. Yu, J. Org. Chem., 2017, 82, 9342-9349.

[13] X. B. Jing, D. D. Yuan, L. Yu, Adv. Synth. Catal., 2017, 359, 1194-1201.

[14] L. Yu, F. L. Chen, Y. H. Ding, ChemCatChem, 2016, 8, 1033-1037.

[15] L. Yu, J. Wang, T. Chen, K. H. Ding, Y. Pan, Chin. J. Org. Chem., 2013, 33, 1096-1099.

[16] L. Yu, J. Wang, T. Chen, Y. G. Wang, Q. Xu, Appl. Organometal. Chem., 2014, 28, 652-656.

[17] Y. G. Wang, L. Yu, B. C. Zhu, L. Yu, J. Mater. Chem. A, 2016, 4, 10828-10833.

[18] J. Młochowski, H. Wójtowicz-Młochowska, Molecules, 2015, 20, 10205-10243.

[19] J. Sun, in: C. G. Yan, Ed., Organic Chemistry, Chemical Industry Press, Beijing, 2012, 74-75.

[20] K. H. Bok, M. M. Lee, G. R. You, H. M. Ahn, K. Y. Ryu, S. J. Kim, Y. Kim, C. Kim, Chem. Eur. J., 2017, 23, 3117-3125.

[21] A. R. Jeong, J. W. Shin, J. H. Jeong, K. H. Bok, C. Kim, D. Jeong, J. Cho, S. Hayami, K. S. Min, Chem. Eur. J., 2017, 23, 3023-3033.

[22] S. Y. Lee, N. Kim, M. M. Lee, Y. D. Jo, J. M. Bae, M. Y. Hyun, S. Yoon, C. Kim, Dalton Trans., 2016, 45, 1727-1736.

[23] J. W. Shin, A. R. Jeong, S. Y. Lee, C. Kim, S. Hayami, K. S. Min, Dalton Trans., 2016, 45, 14089-14100.

[24] T. H. Chen, K. W. Kwong, A. Carver, W. L. Luo, R. Zhang, Appl. Catal. A, 2015, 497, 121-126.

[25] B. Wang, Y. M. Lee, M. S. Seo, W. Nam, Angew. Chem. Int. Ed., 2015, $54,11740-11744$.

[26] K. W. Kwong, T. H. Chen, W. L. Luo, H. Jeddi, R. Zhang, Inorg. Chim. Acta, 2015, 430, 176-183.

[27] G. Varga, S. Ziegenheim, S. Muráth, Z. Csendes, Á. Kukovecz, Z. Kónya, S. Carlson, L. Korecz, E. Varga, P. Pusztai, P. Sipos, I. Pálinkó, J. Mol. Catal. A, 2016, 423, 49-60.

\section{Graphical Abstract}

Chin. J. Catal., 2018, 39: 899-907 doi: 10.1016/S1872-2067(18)63050-5

Recent advances on controllable and selective catalytic oxidation of cyclohexene

Hongen Cao, Boran Zhu, Yufan Yang, Lin Xu, Lei Yu*, Qing Xu*

Yangzhou University; Jiangsu Yangnong Chemical Group Co. Ltd.

Recent advances in controllable and selective catalytic oxidation reactions of cyclohexene are reviewed in this paper, and the contents are classified based on the oxidants used in the reaction.

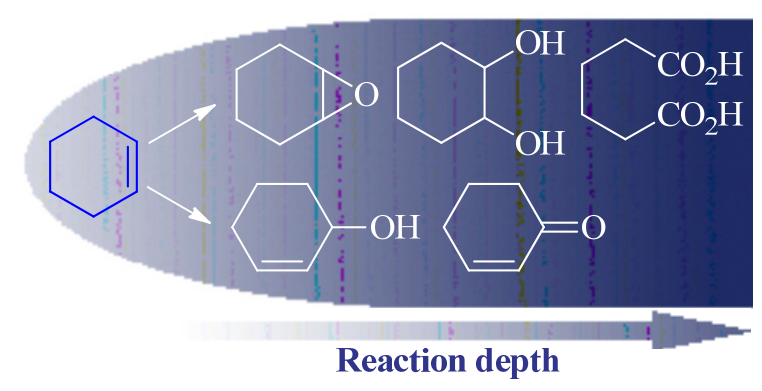


[28] J. Q. Yu, E. J. Corey, Org. Lett., 2002, 4, 2727-2730.

[29] P. Yu, Y. Zhou, Y. W. Yang, R. R. Tang, RSC Adv., 2016, 6, 65403-65411.

[30] A. J. Catino, R. E. Forslund, M. P. Doyle, J. Am. Chem. Soc., 2004, 126, 13622-13623.

[31] Y. C. Li, T. B. Lee, T. Y. Wang, A. V. Gamble, A. E. V. Gorden, J. Org. Chem., 2012, 77, 4628-4633.

[32] M. Lashanizadegan, Z. Zareian, Catal. Lett., 2011, 141, 1698-1702.

[33] J. F. Pan, K. Chen, J. Mol. Catal. A, 2001, 176, 19-22.

[34] I. Kani, S. Bolat, Appl. Organomet. Chem., 2016, 30, 713-721.

[35] F. Jin, C. C. Chang, C. W. Yang, J. F. Lee, L. Y. Jang, S. Cheng, J. Mater. Chem. A, 2015, 5, 8715-8724.

[36] F. Jin, S. Huang, S. Cheng, Y. Wu, C. C. Chang, Y. W. Huang, Catal. Sci. Technol., 2015, 5, 3007-3016.

[37] S. E. Dapurkar, A. Sakthivel, P. Selvam, New J. Chem., 2003, 27, 1184-1190.

[38] M. Zarghani, B. Akhlaghinia, RSC Adv., 2016, 6, 38592-38601.

[39] Z. L. Cheng, W. Sun, Chin. Chem. Lett., 2016, 27, 81-84.

[40] M. Jurado-Gonzalez, A. C. Sullivan, J. R. H. Wilson, Tetrahedron Lett., 2003, 44, 4283-4286.

[41] J. H. Liu, F. Wang, Z. M. Ma, J. Lin, Z. G. Gu, Catal. Commun., 2011, 15, 103-107.

[42] M. T. Alotaibi, M. J. Taylor, D. Liu, S. K. Beaumont, G. Kyriakou, Surf. Sci., 2016, 646,179-185.

[43] N. V. Maksimchuk, K. A. Kovalenko, V. P. Fedin, O. A. Kholdeeva, Adv. Synth. Catal., 2010, 352, 2943-2948.

[44] D. Ruano, M. Díaz-García, A. Alfayate, M. Sánchez-Sánchez, ChemCatChem, 2015, 7, 674-681.

[45] J. C. Wang, Y. H. Hu, G. J. Chen, Y. B. Dong Chem Commun., 2016, 52, 13116-13119.

[46] S. Huang, Y. K. Zhao, R. R. Tang, RSC Adv., 2016, 6, 90887-90896.

[47] C. Antonetti, A. M. R. Galletti, P. Accorinti, S. Alini, P. Babini, K. Raabova, E. Rozhko, A. Caldarelli, P. Righi, F. Cavani, P. Concepcion, Appl. Catal. A, 2013, 466, 21-31.

[48] M. Riahi Farsani, F. Jalilian, B. Yadollahi, H. A. Rudbari, Appl. Organometal. Chem., 2015, 29, 7-11.

[49] J. W. Zhao, Y. Leng, P. P. Jiang, J. Wang, C. J. Zhang, New. J. Chem., 2016, 40, 1022-1028.

[50] X. Y. Shi, P. M. Wang, K. Y. Liu, X. F. Dong, X. Y. Han, J. F. Wei, Appl. Organometal. Chem., 2014, 28, 760-763.

[51] D. Dalmizrak, H. Göksu, M. S. Gültekin, RSC Adv., 2015, 5, 20751-20755.

[52] M. Papastergiou, P. Stathi, E. R. Milaeva, Y. Deligiannakis, M. Louloudi, J. Catal., 2016, 341, 104-115.

[53] A. Mavrogiorgou, M. Baikousi, V. Costas, E. Mouzourakis, Y. Deligiannakis, M. A. Karakassides, M. Louloudi, J. Mol. Catal. A, 2016, 413, 40-55.

[54] A. Simaioforidou, M. Papastergiou, A. Margellou, D. Petrakis, M. Louloudi, J. Mol. Catal. A, 2017, 426, 516-525.

[55] D. R. Godhani, H. D. Nakum, D. K. Parmar, J. P. Mehta, N. C. Desai, J. Mol. Catal. A, 2017, 426(A), 223-237.

[56] R. Kumar, N. Chaudhary, M. Sankar, M. R. Maurya, Dalton Trans., 2015, 44, 17720-17729.

[57] M. Ghorbanlooa, S. Jafaria, R. Bikasa, M. S. Krawczykb, T. Lisc, Inorg. Chim. Acta., 2017, 455, 15-24.

[58] D. R. Godhani, H. D. Nakum, D. K. Parmar, J. P. Mehta, N. C. Desai, J. Mol. Catal. A, 2016, 415, 37-55.

[59] S. K. Mohapatra, P. Selvam, J. Catal., 2007, 249, 394-396.

[60] A. Sinhamahapatra, N. Sutradhar, S. K. Pahari, P. Pal, H. C. Bajaj, M. Jayachandran, A. B. Panda, ChemCatChem, 2011, 3, 1447-1450.

[61] S. J. J. Titinchi, H. S. Abbo, Catal. Today, 2013, 204, 114-124.

[62] B. Thangaraj, C. Jayaraj, V. Ganesh, S. Ayyamperumal, Catal. Com- mun., 2016, 74, 85-90.

[63] R. Luque, S. K. Badamali, J. H. Clark, M. Fleming, D. J. Macquarrie Appl. Catal. A, 2008, 341, 154-159.

[64] J. H. Tong, W. Y. Li, L. L. Bo, H. Wang, Y. S. Hu, Z. X. Zhang, A. Mahboob, J. Catal., 2016, 344, 474-481.

[65] M. Afshari, M. Gorjizadeh, S. Nazari, M. Naseh, J. Magn. Magn. Mater., 2014, 363, 13-17.

[66] S. M. Reddy, M. Srinivasulu, Y. V. Reddy, M. Narasimhulu, Y. Venkateswarlu, Tetrahedron Lett., 2006, 47, 5285-5288.

[67] H. Sugimoto, K. Kitayama, S. Mori, S. Itoh, J. Am. Chem. Soc., 2012, 134, 19270-19280.

[68] H. Sugimoto, K. Ashikari, S. Itoh, Chem. Asian J., 2013, 8, 2154-2160.

[69] H. B. Friedrich, M. Govender, X. Makhoba, T. D. Ngcobo, M. O. Onani, Chem. Commun., 2003, 2922-2923.

[70] T. Naicker, A. K. Datye, H. B. Friedrich, Appl. Catal. A, 2008, 350, 91-102.

[71] K. I. Fujita, T. Ainoya, T. Tsuchimoto, H. Yasuda, Tetrahedron Lett., 2010, 51, 808-810.

[72] K. I. Fujita, M. Yamazaki, T. Ainoya, T. Tsuchimoto, H. Yasuda, Tetrahedron, 2010, 66, 8536-8543.

[73] T. R. Amarante, P. Neves, A. A. Valente, F. A. A. Paz, M. Pillinger, I. S. Gonçalves, J. Catal., 2016, 340, 354-367.

[74] M. Lashanizadegan, S. Rayati, Z. D. Derakhshan, Chin. J. Chem., 2011, 29, 2439-2444.

[75] S. Uruş, H. Adıgüzel, M. Incesu, Chem. Eng. J., 2016, 296, 90-101.

[76] D. Saha, D. K. Hazra, T. Maity, S. Koner, Inorg. Chem., 2016, 55, 5729-5731.

[77] S. H. Jhung, J. H. Lee, A. K. Cheetham, G. Férey, J. S. Chang, J. Catal., 2006, 239, 97-104.

[78] S. R. Amanchi, A. M. Khenkin, Y. Diskin-Posner, R. Neumann, ACS Catal., 2015, 5, 3336-3341.

[79] M. L. Kuznetsov, B. G. M. Rocha, A. J. L. Pombeiro, G. B. Shul'pin, ACS Catal., 2015, 5, 3823-3835.

[80] H. G. T. Nguyen, L. Mao, A. W. Peters, C. O. Audu, Z. J. Brown, O. K. Farha, J. T. Hupp, S. B. T. Nguyen, Catal. Sci. Technol., 2015, 5, 4444-4451.

[81] A. S. Novikov, M. L. Kuznetsov, B. G. M. Rocha, A. J. L. Pombeiro, G. B. Shul'pin, Catal. Sci. Technol., 2016, 6, 1343-1356.

[82] N. Pal, E. B. Cho, D. Kim, C. Gunathilake, M. Jaroniec, Chem. Eng. J., 2015, 262, 1116-1125.

[83] S. K. Pahari, P. Pal, A. Sinhamahapatra, A. Saha, C. Santra, S. C. Ghosh, B. Chowdhury, A. B. Panda, RSC Adv., 2015, 5, 45144-45151.

[84] Y. Usui, K. Sato, M. Tanaka, Angew. Chem. Int. Ed., 2003, 42, 5623-5625.

[85] A. A. Rosatella, C. A. M. Afonso, Adv. Synth. Catal., 2011, 353, 2920 $-2926$.

[86] A. Theodorou, I. Triandafillidi, C. G. Kokotos, Eur. J. Org. Chem., 2017, 2017, 1502-1509.

[87] H. Alper, M. Harustiak, J. Mol. Catal., 1993, 84, 87-92.

[88] P. F. Zhang, Y. T. Gong, Y. Q. Lv, Y. Guo, Y. Wang, C. M. Wang, H. R. Li, Chem. Commun., 2012, 48, 2334-2336.

[89] Y. N. Wei, H. Li, F. Yue, Q. Xu, J. D. Wang, Y. Zhang, RSC Adv., 2016, 6, 107104-107108.

[90] D. X. Yang, T. Jiang, T. B. Wu, P. Zhang, H. L. Han, B. X. Han, Catal. Sci. Technol., 2016, 6, 193-200.

[91] M. Sankaralingam, Y. M. Lee, W. Nam, S. Fukuzumi, Inorg. Chem., 2017, 56, 5096-5104.

[92] S. J. Li, Y. G. Wang, Tetrahedron Lett., 2005, 46, 8013-8015.

[93] M. Bazarganipoura, M. Salavati-Niasari, Chem. Eng. J., 2016, 286, 259-265. 
[94] M. S. nejad, G. Ghasemi, M. V. Martínez-Huerta, M. Ghiaci, J. Mol. Catal. A, 2015, 406, 118-126.

[95] J. Dou, Y. Tang, L. Nguyen, X. Tong, P. S. Thapa, F. F. Tao, Catal. Lett., 2017, 147, 442-452.

[96] Z. C. Chen, R. L. Luck, Green Chem., 2016, 18, 3354-3359.

[97] C. A. Henriques, A. Fernandes, L. M. Rossi, M. F. Ribeiro, M. J. F. Calvete, M. M. Pereira, Adv. Funct. Mater., 2016, 26, 3359-3368.

[98] F. Parra da Silva, R. V. Gonçalves, L. M. Rossi, J. Mol. Catal. A, 2017, 426, 534-541.

[99] G. Q. Yang, H. Y. Du, J. Liu, Z. Zhou, X. B. Hu, Z. B. Zhang, Green Chem., 2017, 19, 675-681.

[100] A. Farokhi, H. Hosseini-Monfared, New. J. Chem., 2016, 40, 5032-5043.

[101] G. Q. Zou, D. Jing, W. Z. Zhong, F. P. Zhao, L. Q. Mao, Q. Xu, J. F. Xiao, D. L. Yin, RSC Adv., 2016, 6, 3729-3734.

[102] S. K. Pahari, P. Pal, D. N. Srivastava, S. Ch. Ghosh, A. B. Panda, Chem. Commun., 2015, 51, 10322-10325.

[103] H. Martínez, M. F. Cáceres, F. Martínez, E. A. Páez-Mozo, S.
Valange, N. J. Castellanos, D. Molina, J. Barrault, H. Arzoumanian, J. Mol. Catal. A, 2016, 423, 248-255.

[104] E. Tempesti, E. Montoneri, L. Giuffre, G. Airoldi, J. Org. Chem., 1980, 45, 4278-4280.

[105] X. M. Yang, L. P. Zhou, Y. Chen, C. Chen, Y. L. Su, H. Miao, J. Xu, Catal. Commun., 2009, 11, 171-174.

[106] G. Y. Liu, R. R. Tang, Z. Wang, Catal. Lett., 2014, 144, 717-722.

[107] P. F. Zhang, Y. Wang, J. Yao, C. M. Wang, C. Yan, M. Antonietti, H. R. Li, Adv. Synth. Catal., 2011, 353, 1447-1451.

[108] W. Y. Zhang, A. Bariotaki, L. Smonou, F. Hollmann, Green Chem., 2017, 19, 2096-2100.

[109] Y. H. Cao, H. Yu, H. J. Wang, F. Peng, Catal. Commun., 2017, 88, 99-103.

[110] E. J. Horn, B. R. Rosen, Y. Chen, J. Tang, K. Chen, M. D. Eastgate, P. S. Barab, Nature, 2016, 533, 77-81.

[111] S. R. Waldvogel, M. Selt, Angew. Chem. Int. Ed., 2016, 55, 12578-12580.

\title{
环己烯可控选择性催化氧化的最新进展
}

\author{
曹洪恩 ${ }^{\mathrm{a}}$, 朱柏燃 ${ }^{\mathrm{a}}$, 杨钰帆 ${ }^{\mathrm{a}}$, 徐 林 ${ }^{\mathrm{a}, \mathrm{b}}$, 俞 䂞 ${ }^{\mathrm{a},}{ }^{*}$, 徐 清 ${ }^{\mathrm{a}, \#}$ \\ a扬州大学化学化工学院及园艺与植物保护学院农药研究所, 江苏扬州225009

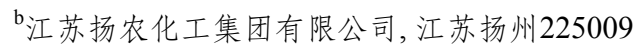

\begin{abstract}
摘要: 环己烯是一种价格低廉易得的大宗化工原料, 通常由苯选择性加氢来合成. 该化合物虽然分子结构简单, 但却有两 个不同的反应位点. 随着反应所发生的位点与反应深度的不同, 环已烯的氧化反应可生成一系列不同氧化程度与官能团 的产物的混合物. 环已烯双键的氧化反应, 可生成环氧环己烷, 而环氧环己烷进一步水解, 则生成 1,2-环已二醇, 其中, 随着 使用不同催化剂导致的反应机理差异, 产物可分别为顺式或反式结构. 在强氧化剂作用下, 环已烯双键充分氧化, 可生成 己二酸. 环己烯烯丙基 C-H 键氧化, 则可随着反应深度的不同分别生成 2-环已烯醇与 2-环已烯酮.

上述环已烯氧化产物都是重要的有机化工中间体. 其中, 环氧环己烷是农药杀螨剂的主要原料, 也用作合成表面活性 剂、橡胶助剂等有用产品; 1,2 -环已二醇可用于合成化工中间体邻苯二酚; 环已烯醇与环己烯酮是生产除草剂、香水、药 物的原料; 已二酸则是合成重要产品尼龙-6,6 的原料. 因此, 随着市场需求的变化, 对环已烯氧化反应进行选择性控制, 提 高其中某种产物的选择性, 是重要的化工合成技术, 有着巨大的应用潜力; 从而控制反应历程与深度是有机化工合成工艺 研究中最具有挑战性的研究课题之一, 有很好的科学意义.

目前, 人们对环己烯的选择性控制氧化反应已进行了广泛的研究. 该反应可使用金属催化剂, 包括铁、钴、镍、锰、 铬、钒、铇、铜、钛、金、银、铋、钱、钿、镉等; 也可以使用无金属催化剂如磺酸、2,2,2-三氟苯乙酮、类石墨相碳化 氮 $\left(\mathrm{g}-\mathrm{C}_{3} \mathrm{~N}_{4}\right)$ 等. 反应可使用化学氧化剂, 如间氯过氧苯甲酸、醋酸碘苯、过氧叔丁醇等, 也可使用更加清洁的过氧化氢、 分子氧. 研究表明, 催化剂的种类、用量, 以及反应溶剂、温度、氧化剂等一系列外在条件, 可以影响环己烯氧化反应的选 择性. 本文以反应所使用的氧化剂归类, 总结了该课题的最新研究进展, 以期对从事环己烯可控选择性氧化的学术与工业 研究人员有所帮助.
\end{abstract}

关键词: 环己烯; 选择性氧化; 绿色化学; 环氧环已烷; 环已二醇; 己二酸; 环已烯醇; 环己烯酮

收稿日期: 2018-01-08. 接受日期: 2018-02-15. 出版日期: 2018-05-05.

*通讯联系人. 电话: 13665295901; 传真: (0514)87975244; 电子信箱: yulei@yzu.edu.cn

\#通讯联系人. 电话: 13857745327 ; 传真: (0514)87975244; 电子信箱: xuqing@yzu.edu.cn 基金来源：国家自然科学基金 $(21202141,21672163)$; 江苏省高校优势学科项目.

本文的电子版全文由Elsevier出版社在ScienceDirect上出版(http://www.sciencedirect.com/science/journal/18722067). 